\title{
Determinants of Retail Investors Behavior and its impact on Investment Decision
}

\author{
Nadeem lqbal ${ }^{1}$, Naveed Ahmad ${ }^{2, *}$, Maira Abrar $^{3}$, Aisha Hassan ${ }^{3}$ \\ ${ }^{1}$ Faculty of Business Administration, Baha-ud-Din Zakariya University, \\ Bosan Road, Multan 60000, Punjab, Pakistan \\ ${ }^{2}$ Faculty of Management Sciences, Indus International Institute, D. \\ G. Khan, Punjab \\ ${ }^{3}$ Baha-ud-Din Zakariya University, D. G. Khan, Multan, Punjab, Pakistan
}

*E-mail address: naveeddgk2010@gmail.com

\section{ABSTRACT}

Behavioral finance is an emerging science, and a academic study that exploits the irrational nature of in influences to some extent by our prejudices and perceptic Behavioral finance concentrates on irrational behavior tl prices. The rationale of this manuscript study is to ana behavior in Pakistani stock market. The studv used pn re thely no and developing field of Pakistan
oping field of
decisions are questionnaire. Questions related to investors and determinants of investor behavior were included using a five point scale. Data collect of wo yzed through SPSS and spread sheet. Analytic hierarchy process (AHP) is used to fin ane retive significance of different behavioral qualities of the investors in contriby verall il estment behavior. AHP is one of multi Criteria decision making method to derive atio se es from Ared comparisons. The findings suggest that the dimension of overconfidence $p$ lay

Keywords: behavior finap investmen icion; overconfidence; risk preference; optimism

1. INTROP

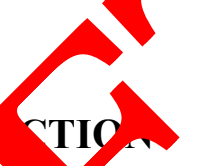
to expec ed shock and news it takes no time to bang the market tricks. However at the samo stock market is flexible and recovers rapidly after shocks. The role and significa of individual investors and their trading behavior in Pakistani stock market is also very cal. Disparate institutional investors, individual investors are assumed to be less informal, have psychological biases and also through of as the recognizable noise traders in the stock prices. With this perception regarding the individual investors, mainstream of trading strategies and stock market policies are planned and focused to their institutional counterparts thereby ignoring the individual investor's interests to some degree. The rationale of this manuscript study is to analyses the determinants of individual investor behavior in Pakistani stock market. 


\section{OBJECTIVE OF THE STUDY}

The purpose of the study is in the direction of identifying the determinants of investment behavior and their relative importance in shaping the behavior of individual investors.

\section{1. Variables of the study}

Independent variables: Investor's behavior of which determinants are:

a) Overconfidence.

b) Investor optimism

c) Investor's involvement

d) Risk preference

Dependant variable: Investment decision

\section{2. Theoretical background}

Behavioral finance is an emerging science, and a rela rely and deyeloping field of academic study that exploits the irrational nature of iny yos investment decisions are influences to some extent by our prejudices and erceptions that o not meet the criteria of rationality. Behavioral finance concentrates a irrational behavior that can affect investment decision and market prices. It tries to im ve under landing and explaining how emotion and cognitive errors investors and the decis mak ig process. Many researchers consider that the study of psychology an sociar shack considerable light on the efficiency of financial markets as well as $h \mathrm{p}$ to stock market volatility and other anomalies. The role of behavioral finance is 1 to dininish the primary work that has been done by proponents of efficient $p$ am hypothe is. Rather, it is to examine the importance of tranquil unrealistic behavioral sump ons and rake it more realistic. It does this by adding more individual aspects of process in financial markets. Without these contributions of behay ral fina definite aspects of financial markets cannot be understood. Despite tr ortance or dividual's investment decisions, we know little about the factors that influ fee th Finance research has often ignored the individual investor's decision makin process wh king financial investment decisions. There is a need to develop beha oral $p$ gigm to probe the determinants of investor behavior and their impact on individual or's fir ncial decision making outcomes. For the purpose of this research, we adontad an roacl favored by traditional Economist. The current study examines beha 1ors biases dividual investors' that Behavioral Finance Micro (BFMI)

\subsection{I arcm puestions}

This dy will help to answer the following queries:

1. Does overconfidence behavior plays important role in investment decision?

2. Does investor keep optimistic views about future stock-market condition?

3 . Is the investor involvement outcome of investment objective?

4. Is risk preference outcome of investment objective?

\section{4. Literature Review}

The proposal that has dominated finance is Efficient Market Hypothesis (EMH). There are three basic theoretical wiles that form the basis of the EMH. The first and most noteworthy is that investors are rational. Secondly it is based on the idea that everyone takes 
suspicious account of all accessible information prior to making investment decisions. It is linked to internal consistency. The third principle is that the decision maker always pursue self-interest.

Behavioral finance is a cram of the markets that drawn on psychology, throwing more light on why people purchase or sales the stocks and even why they do not buy stocks at all. This research on investor behavior helps to explain the various 'market anomalies' that confront standard theory. Behavior finance encompasses research that drops the conventional assumption of expected utility maximization with rational investors in efficient market. The two building blocks of behavioral finance are cognitive psychology and the limits to graitrage (Ritter, 2003). Cognitive refers to how people think and the limit to arbitrage wb on man is inefficient.

Much of the basic theories of behavior finance concern with a serim of conce under the general heading of 'bounded rationality, associated $y$ ith Herbo Sim on (1974.1983). It relates to cognitive restrictions on decision-makip As a esult, aman behavior is made on the basis of simplified procedures or heurist (1 yand K lneman, 19740). This is steady with the study done by Slovic (197/ on in nent isk-taking behavior. He found that, man has limitations as a processor ormation. ople also tend to be over react to information (De Bondt Thalor, 1985, 108

Shiller (1999) surveys some of the basic ideas in encioral fin theory. Regret theory, Anchoring, and Market oy r-and under-reacion. Prospect theory introduced by Khaneman and Tvernsky $(1979,1$ 1,1986) sus gests that people respond differently to equivalent situations depending on wh er it is pr sented in the perspective of a loss or a gain, "Regret theory" (Larrick Boles, 1) nother theory that deals with people's emotional reaction to giving made of judgment. Anchoring (Yates ,1990), is a phenomenon in which, in the absence of be er ito cion, investors assume current prices are right. Market over-or under-regation (Dek ndt and Thaler, 1985), is the consequence of investors putting too much we gnt recent ews at the expense of other people show overconfidence. They tend to om more op imistic when the market goes up and more pessimistic when the mark ones prices fall too much on bad environment.

It has long been $r$ owned tha source of judgment and decision biases, such as time reminiscence, and a ent are limit, human information processing capacity is finite. Therefore, there nee co imperfect decision-making procedure, or most familiar psychological bases can be vio $d$ as outgrowths of heuristic simplification, self- deception, and emotion sed jy ment. Shudy done by Kent, Hirshleifer and Subrahmanyan (2001) had found the evia for sys matic cognitive errors made by investors and these biases affects prices

Acc ling to nt,et al. (2001). The most frequent behavior that most investors do who al invecment decision are (1) Investor frequently do not participate in all asset and so ity categories, (2) Individual investors demonstrate loss-averse behavior, (3) Investors past performance as gauge of future performance in stock purchase decisions, (4) Investc, s trade too aggressively, (7) Investors behave parallel to each other, and (8) Investors are influenced by historical high or low trading stocks.

\section{RESEARCH METHODOLOGY}

Data for the study is secondary collected through online survey report and different websites in the form retail stock market investors. Questions related to investors profile and determinants of investor behavior were included using a five point scale. Data collected were 
analyzed through SPSS and spread sheet. Analytic hierarchy process (AHP) is used to find the relative significance of different behavioral qualities of the investors in contributing overall investment behavior. AHP is one of multi Criteria decision making method to derive ratio scales from paired comparisons.

The study identified four broad dimensions of investor behavior that could have an impact on their investment decisions (Overconfidence, |Investor Optimism, Investor Involvement and Risk Preferences) that were further divided into different factors and respondents were asked to rate each factor. On the basis of the overall responses of the investors and the ratings that they assign to the factors of the each dimension AHP detarmine the relative weights for each dimension of the investment behavior and priori aes the in terms of their level of contribution in the formation of behavior of the inves ent behav and priorities them in terms of their level of contribution in the formation $\mathrm{fe}$. ior of $t$ investor.

\section{ANALYSIS AND INTERPRETATION PROFILE OF RF oPONDL}

The analysis was based on the data collected from res, nnden sing questionnaire. The various demographic and economic factors regarding th -10, ondents allows:

The gender ratio of respondents: Of the total res ndents. $75.64 \%$ were males and 24.36 $\%$ were females.

The age group distribution of respondents: Age o. years. It was aimed to include investors fr 11 categories so that the pattern will get an equitable distribution. Majority of responden $\mathrm{S}$. eur 30-40 year age group $(34.62 \%)$ followed by $40-50$ year age group $(28.21 \%)$, vate erganizations $(33.33 \%)$ Self employed individuals (24.36\%) Business (1 $1 . \%$ ) and 1 grjcultural background (6.41\%).

The education level distribru of $y$ majority of investors is having a Bachelors degree $(52.56 \%$ or th that most of the respondents in this study have good educational backgrou

The investment exp rienc respondents: From the analysis of investment experience of investors. It wo found that ority of respondents have an experience of 5-10 years (41.02\%). fol wed b investors having an experience of less than 5 year (39.74\%).

Stock moniton behavi of respondents: Of the total respondents, $87.18 \%$ daily monitor their ments st cks and they look for short term profits from favorable price mo sment $10.26 \%$ of the investors monitor their investment weekly and the rest $2.56 \%$ of the or monthly. Investors with different level of investments are observed to have s. ificantly different monitoring behavior. The investors with high amount of investmen $1 \mathrm{~d}$ those with short horizon tend to monitor their investments more frequently when compared to those with low amount of investments and long term investors.

Investment objectives of respondents: By analyzing the responses it could be inferred that $64.15 \%$ of the investor's objectives is to take benefit from the daily price fluctuations. 11.54 $\%$ of the investors make their investment to earn steady income in the form of dividends. $26.93 \%$ of the investors aim for growth objectives. While rest of the investors have multiple investment objectives. 


\section{ANALYSIS OF DETERMINANTS OF INVESTOR BEHAVIOR FREQUENCY ANALYSIS OF OVERCONFIDENCE}

Table 1. Frequency Results for Overconfidence.

\begin{tabular}{|c|c|c|c|c|c|c|}
\hline Question & S. D(1) & $D(2)$ & $\mathbf{N}(3)$ & $A(4)$ & S. A(5) & Total \\
\hline $\begin{array}{l}\text { I am confident of my } \\
\text { ability to do better than } \\
\text { others in picking stocks } \\
\text { (Stock Picking Ability) }\end{array}$ & $\begin{array}{c}2 \\
(2.56 \%)\end{array}$ & $\begin{array}{c}12 \\
(15.38 \%)\end{array}$ & $\begin{array}{c}15 \\
(19.24 \%)\end{array}$ & $\begin{array}{c}17 \\
(21.80 \%)\end{array}$ & & \\
\hline $\begin{array}{l}\text { I am fully responsible } \\
\text { for the results of my } \\
\text { investment decisions. } \\
\text { (Self-Contorl) }\end{array}$ & $\begin{array}{c}4 \\
(5.13 \%)\end{array}$ & $\begin{array}{c}13 \\
(16.67 \%)\end{array}$ & $\begin{array}{c}14 \\
(17.95 \%\end{array}$ & & & $\begin{array}{c}78 \\
(100 \%)\end{array}$ \\
\hline $\begin{array}{l}\text { I have complete } \\
\text { knowledge of stock } \\
\text { market (Market } \\
\text { Knowledge) }\end{array}$ & $\begin{array}{c}3 \\
(3.85 \%)\end{array}$ & $\begin{array}{c}11 \\
(14.10 \%)\end{array}$ & & & $\begin{array}{c}30 \\
(38.46 \%\end{array}$ & $\begin{array}{c}78 \\
(100 \%)\end{array}$ \\
\hline
\end{tabular}

The frequency results $0^{f}$ these iree stat Ments tell reveals that investors have high level of Overconfidence a th li level of confidence on their Stock Picking Abilities, high level of S if Contro $\mathrm{d}$ greater confidence of having Market Knowledge as majority of investors $g$ at ting of 4 y above in case of each parameter.

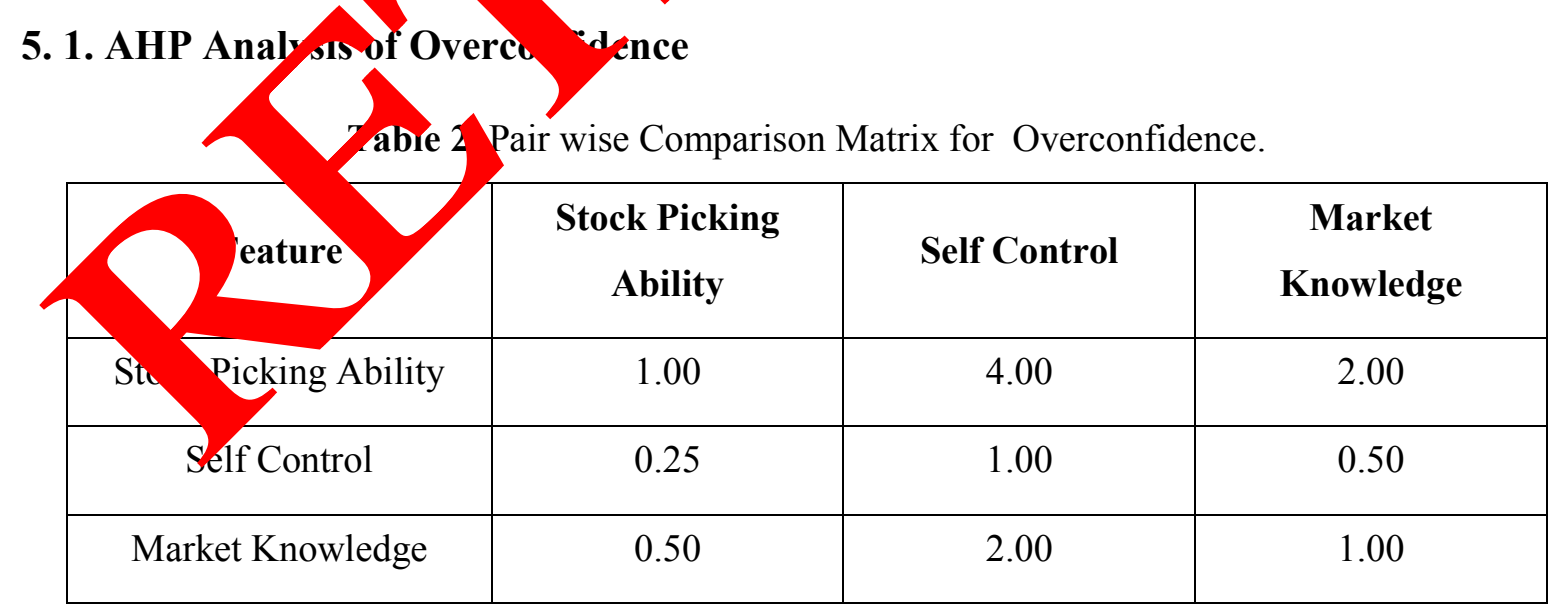


Table 3. Rank Matrix for Overconfidence.

\begin{tabular}{|c|c|c|c|c|}
\hline Feature & $\begin{array}{c}\text { Stock Picking } \\
\text { Ability }\end{array}$ & $\begin{array}{c}\text { Self } \\
\text { Control }\end{array}$ & $\begin{array}{c}\text { Market } \\
\text { Knowledge }\end{array}$ & Average \\
\hline Stock Picking Ability & 0.57 & 0.57 & 0.57 & 0.57 \\
\hline Self Control & 0.14 & 0.14 & 0.14 & 0.14 \\
\hline Market Knowledge & 0.29 & 0.29 & 0.29 & \\
\hline Total & 1.00 & 1.00 & 1.00 & \\
\hline \multicolumn{2}{|c|}{ Feature } & $\%$ & & \\
\hline \multicolumn{2}{|c|}{ Stock Picking Ability } & $57 \%$ & & \\
\hline \multicolumn{2}{|c|}{ Market Knowledge } & $29 \%$ & & \\
\hline \multicolumn{2}{|c|}{ Self Control } & 14 & 3 & \\
\hline
\end{tabular}

The Analytical Hierarchical Process de nonea ne relative weights of each factor of the dimension of Overconfidence the on all dimension of Overconfidence the most prominent factor was the Stocl Pickin Ability at result in successful investment, (approx. $57 \%$ ) followed by Market no proximate weights of $29 \%$ and Self Control ability with $14 \%$

\begin{tabular}{|c|c|c|c|c|c|c|}
\hline & S. D(1) & $D(2)$ & $\mathbf{N}(3)$ & $A(4)$ & S. A(5) & Total \\
\hline $\begin{array}{l}\text { investmo } \\
\text { in next 12 ths (Increased } \\
\text { Inves ents) }\end{array}$ & $\begin{array}{c}22 \\
(28.20 \%)\end{array}$ & $\begin{array}{c}16 \\
(20.50 \%\end{array}$ & $\begin{array}{c}8 \\
(10.27 \%)\end{array}$ & $\begin{array}{c}13 \\
(16.67 \%)\end{array}$ & $\begin{array}{c}19 \\
(24.36 \%)\end{array}$ & $\begin{array}{c}78 \\
(100 \%)\end{array}$ \\
\hline $\begin{array}{l}\text { The prices of stocks will } \\
\text { increase in next } 12 \text { months } \\
\text { (price Increase Expectation) }\end{array}$ & $\begin{array}{c}16 \\
(20.51 \%)\end{array}$ & $\begin{array}{c}15 \\
(19.24 \%)\end{array}$ & $\begin{array}{c}11 \\
(14.10 \%)\end{array}$ & $\begin{array}{c}15 \\
(19.24 \%)\end{array}$ & $\begin{array}{c}21 \\
(26.32 \%)\end{array}$ & $\begin{array}{c}78 \\
(100 \%)\end{array}$ \\
\hline $\begin{array}{l}\text { If the BSE index drops by } \\
<3 \% \text { tomorrow. I would } \\
\text { suggest that it will recover } \\
\text { most of its losses in a few } \\
\text { days (Index Recover) }\end{array}$ & $\begin{array}{c}16 \\
(20.51 \%)\end{array}$ & $\begin{array}{c}10 \\
(12.82 \%)\end{array}$ & $\begin{array}{c}12 \\
(15.39 \%)\end{array}$ & $\begin{array}{c}20 \\
(25.64 \%)\end{array}$ & $\begin{array}{c}20 \\
(25.64 \%)\end{array}$ & $\begin{array}{c}78 \\
(100 \%)\end{array}$ \\
\hline
\end{tabular}


By analyzing the responses the overall Optimism among the investors is low but 51.38 $\%$ of investors do believe that even if the market falls, it will recover within a few days.

\section{1. AHP Analysis of Optimism}

Table 6. Pair wise Comparison Matrix for Optimism.

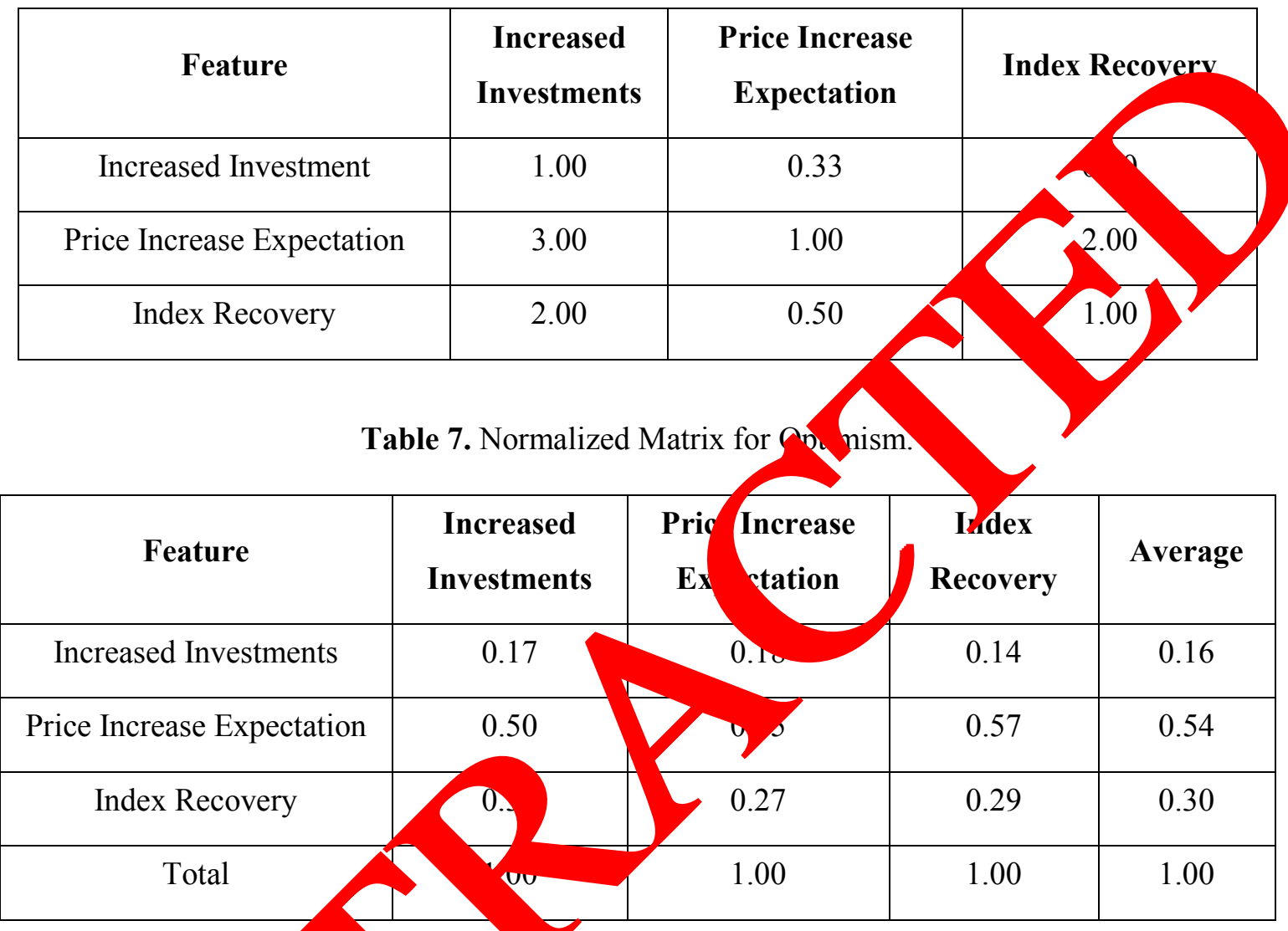

\begin{tabular}{|l|c|c|}
\hline & ble 8. Rank Matrix for Optimism. \\
\hline Inceature & $\%$ & Rank \\
\hline Increased Investments & $54 \%$ & 1 \\
\hline
\end{tabular}

\section{2. Interpretation}

The second determinant Investor Optimism was measured in terms of investor's outlook of the stock market. AHP analysis assigned the highest rank to the factor Price Increase Expectation (54\%) followed by Recovery of the Index $30 \%$. Only $16 \%$ of respondents are interested in Increasing Investments. On the whole the optimism among the investors is very low. 


\section{FREQUENCY ANALYSIS OF INVOLVEMENT}

Table 9. Frequency Results for Involvement.

\begin{tabular}{|c|c|c|c|c|c|c|}
\hline Question & S. D(1) & $\mathbf{D ( 2 )}$ & $\mathbf{N ( 3 )}$ & $\mathbf{A}(4)$ & S. A(5) & Total \\
\hline $\begin{array}{c}\text { I am actively involved in } \\
\text { trade activity (Trade } \\
\text { Activity) }\end{array}$ & 2 & 1 & 19 & 21 & 35 & 78 \\
$(2.56 \%)$ & $(1.28 \%)$ & $(24.36 \%)$ & $(26.92 \%)$ & $(44.88 \%$ \\
\hline $\begin{array}{c}\text { I make investment for } \\
\text { making money quickly } \\
\text { (Quick Money) }\end{array}$ & 7 & 4 & 13 & 29 & 78 \\
$(8.97 \%)$ & $(5.13 \%)$ & $(16.67 \%)$ & $(37.18 \%)$ & $(32.0$ \\
\hline
\end{tabular}

Analyzing responses it could be inferred that 69.2 ondents are involved in trade activity to make Quick Money.

\section{1. AHP Analysis of Involvement}

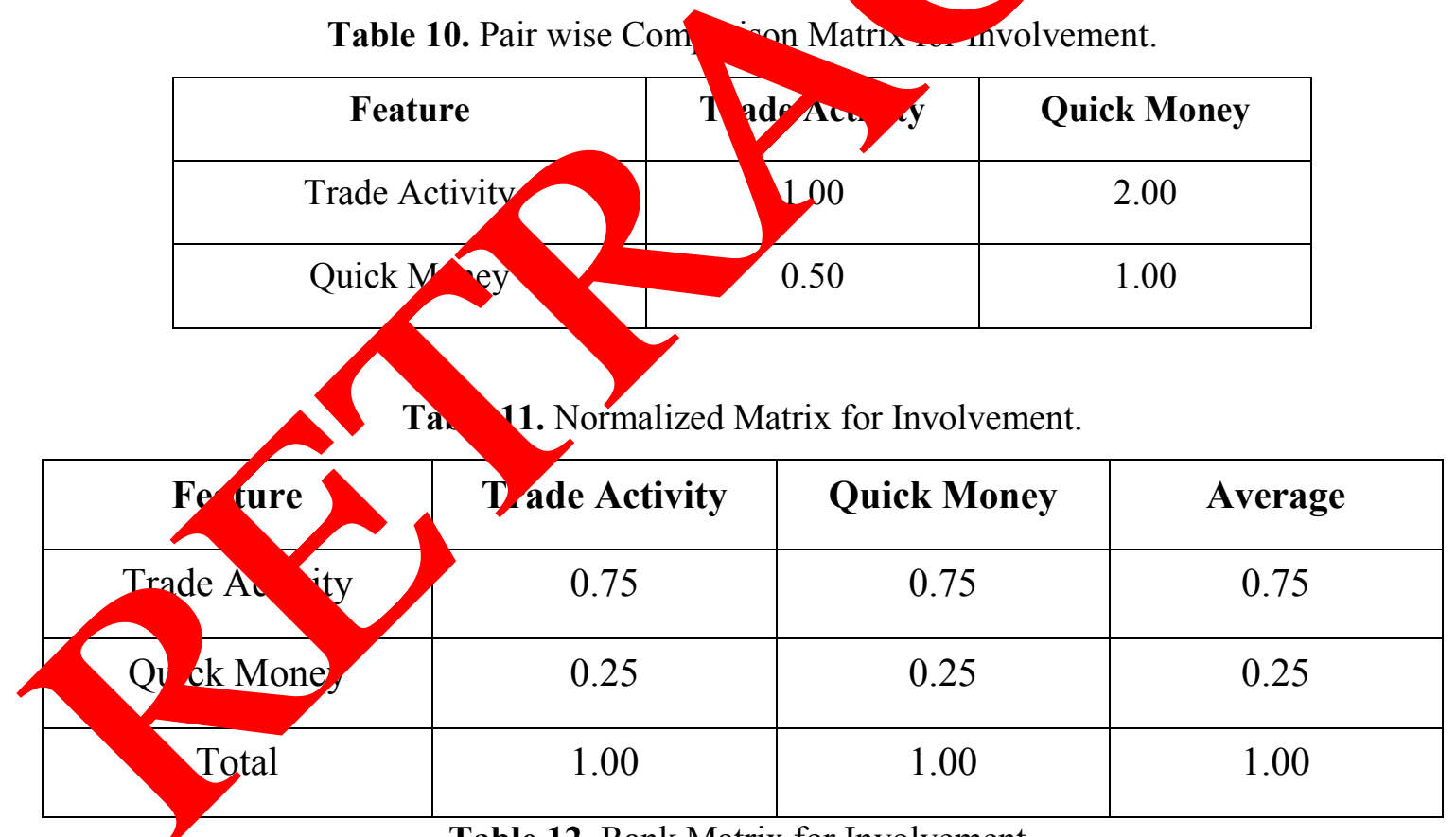

Table 12. Rank Matrix for Involvement.

\begin{tabular}{|c|c|c|}
\hline Feature & \% & Rank \\
\hline Trade Activity & $75 \%$ & 1 \\
\hline Quick Money & $25 \%$ & 2 \\
\hline
\end{tabular}


To measure the overall Involvement of Investors in stock trading two factors namely level of Trade Activity and motive towards making Quick Money were analyzed. On the basis of responses for the investors AHP determined Trade Activity has the highest weights approximately $75 \%$ while the attitude of making Quick Money weights $25 \%$ approx.

\section{2. Frequency Analysis of Risk Preferences/Attitudes}

Table 13. Frequency Results for Risk Preferences/Attitudes.

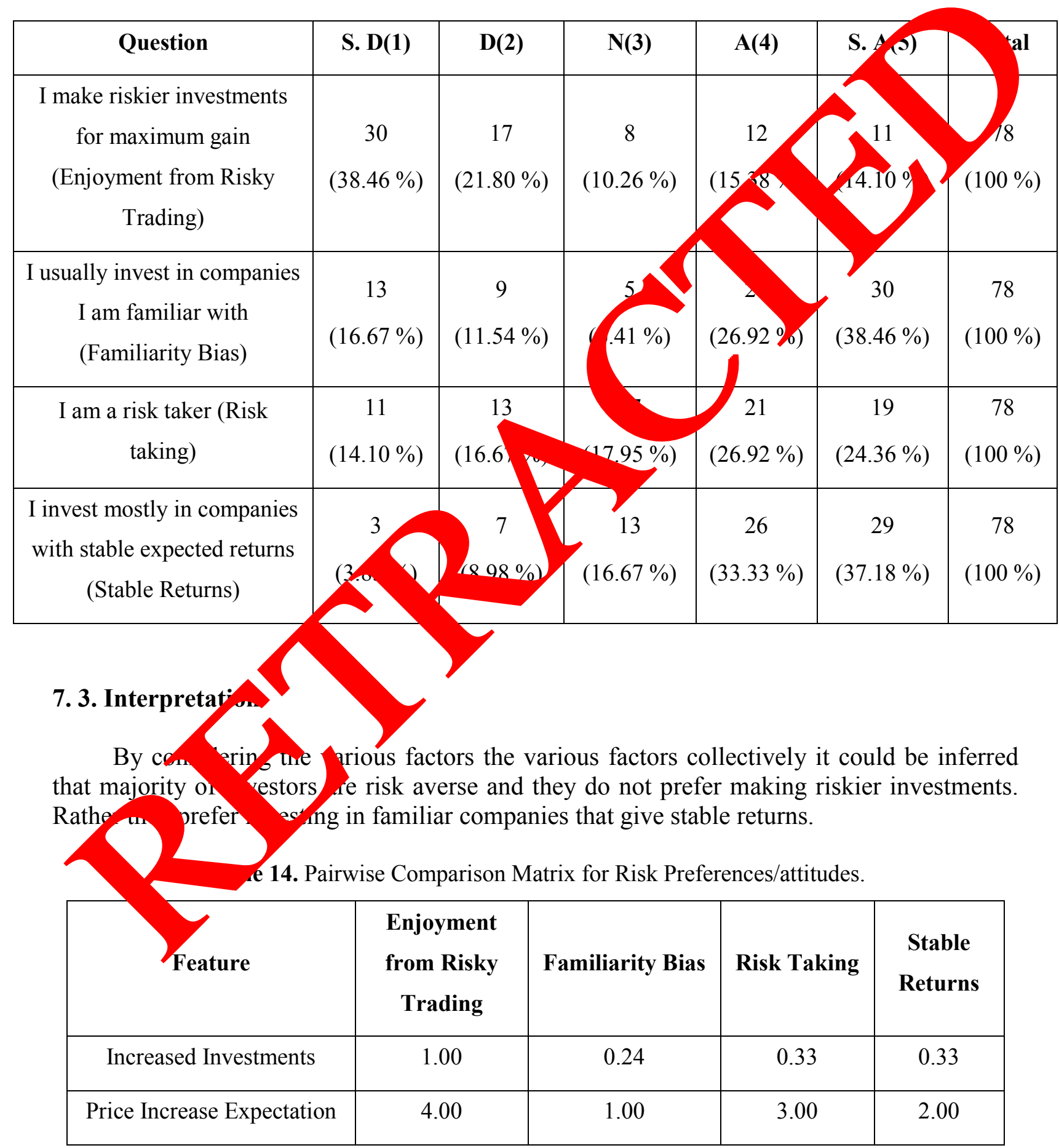




\begin{tabular}{|c|c|c|c|c|}
\hline Index Recovery & 3.00 & 0.33 & 1.00 & 0.50 \\
\hline Total & 3.00 & 0.50 & 2.00 & 1.00 \\
\hline
\end{tabular}

Table 15. Normalized Matrix for Risk Preferences/attitudes.

\begin{tabular}{|c|c|c|c|c|c|}
\hline Feature & $\begin{array}{c}\text { Enjoyment } \\
\text { from Risky } \\
\text { Trading }\end{array}$ & $\begin{array}{c}\text { Familiarity } \\
\text { Bias }\end{array}$ & $\begin{array}{c}\text { Risk } \\
\text { Taking }\end{array}$ & $\begin{array}{c}\text { Stable } \\
\text { Returns }\end{array}$ \\
\hline $\begin{array}{c}\text { Enjoyment from Risky } \\
\text { Trading }\end{array}$ & 0.09 & 0.12 & 0.05 & \\
\hline Familiarity Bias & 0.36 & 0.48 & 0.47 & 0.0 .46 \\
\hline Risk Taking & 0.27 & 0.16 & & 0.16 \\
\hline Stable Returns & 0.27 & 0.24 & 0.32 & 0.26 & 0.27 \\
\hline Total & 1.00 & 1.00 & 1.00 & 1.00 & 1.00 \\
\hline
\end{tabular}

Table 16. Rank Matrix f King ferences/attitudes.

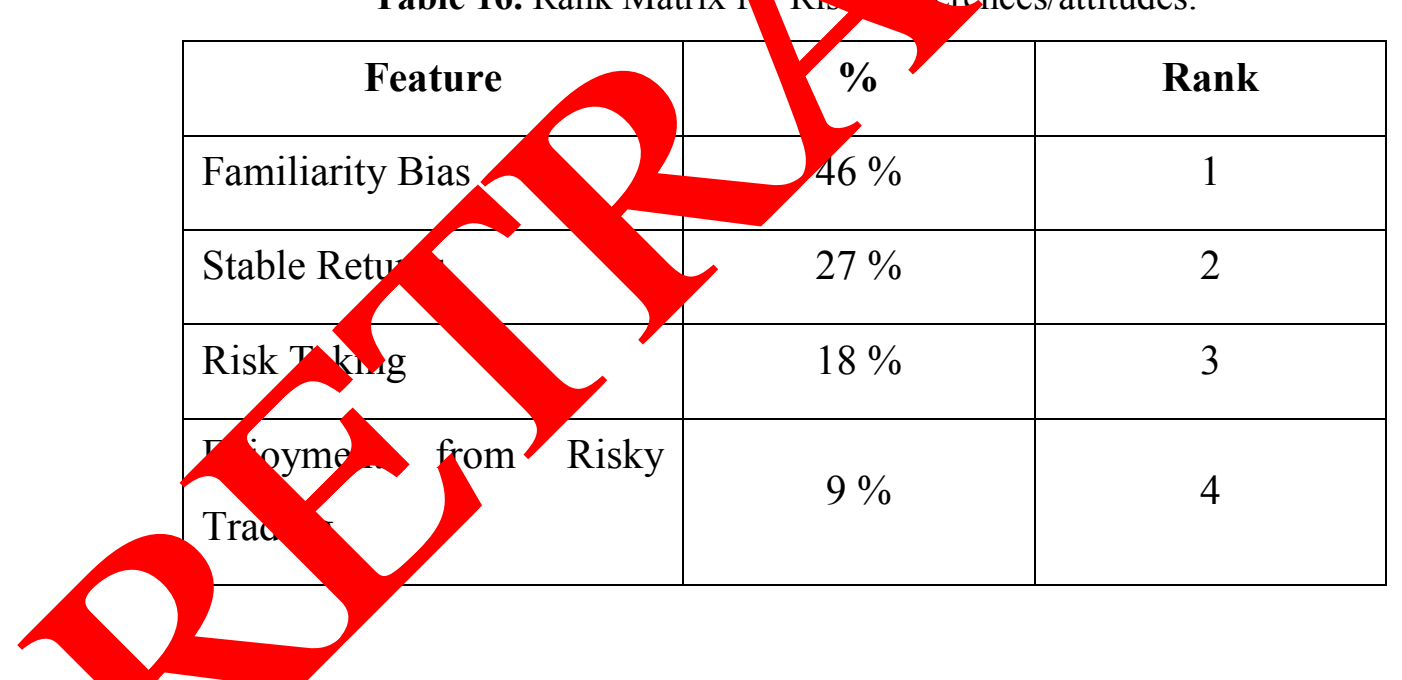

A analysis revels that investors have greater fear of un-known and uncertainty and to avoid it. 1 /make investments in the stocks of the companies which they are familiar with. The factor of familiarity bias gets the highest rank among all four factors with weights of 46 $\%$ approx.

The tendency of investing in stocks with stable returns weights about $27 \%$. These two factors basically reveal the tendency of risk aversion of the investor. While the other two factors Risk taking and enjoying Risky trading measures the risk loving attitude of the investors. The cumulative score of risk preference reveals that investors are risk averse. 


\section{4. AHP Analysis of Determinants of Investor Behavior}

Table 17. Pairwise Comparison Matrix of Behavioral Determinants.

\begin{tabular}{|c|c|c|c|c|}
\hline Feature & Overconfidence & $\begin{array}{c}\text { Investor } \\
\text { Optimism }\end{array}$ & Involvement & $\begin{array}{c}\text { Risk } \\
\text { Preferences } \\
\text { / Attitudes }\end{array}$ \\
\hline Overconfidence & 1.00 & 5.00 & 3.00 & 0.20 \\
\hline Investor Optimism & 0.20 & 1.00 & 0.33 \\
\hline Involvement & 0.33 & 3.00 & 5.00 \\
\hline Risk Preferences / Attitudes & 0.50 & \\
\hline
\end{tabular}

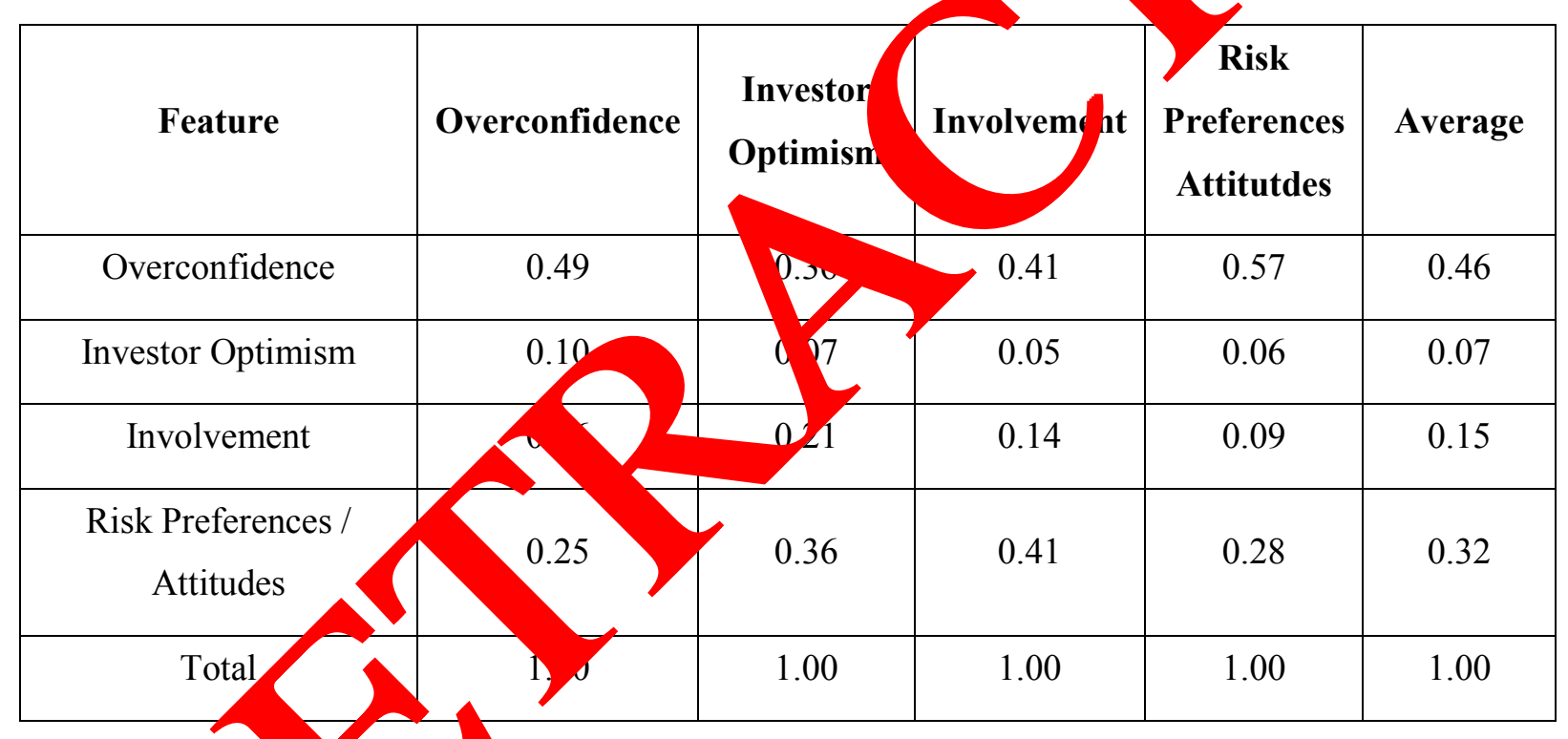

\begin{tabular}{|l|c|c|}
\hline Table 19. Rank Matrix of Behavioral Determinants. \\
\hline Feature & \% & Rank \\
\hline Overconfidence & $46 \%$ & 1 \\
\hline Risk Preferences / Attitudes & $32 \%$ & 2 \\
\hline Involvement & $15 \%$ & 3 \\
\hline Investor Optimism & $7 \%$ & 4 \\
\hline
\end{tabular}


AHP determined that Overconfidence carries more than $64 \%$ weight, so it is the most prominent behavioral dimension that has greater impact in the formation that has greater impact in the formation of overall behavior followed by Risk Preferences/Attitudes with a weight of $32 \%$ and other two dimensions involvement and Investor Optimism with weights $15 \%$ and $7 \%$ respectively

\section{FINDINGS}

This paper analyses investment behavior of individual investor in terms behavioral dimensions VIZ; Overconfidence, Investor involvement, Optip $n$ and $\mathrm{R}$ attitude that are measured in terms of different factors. The findings sugs that $t$ ] dimension of overconfidence plays an important role in the determinatio' of overal havi or. Followed by the role of risk preferences, involvement and optimism.

In this study overconfidence bias is measured in terms of ou cors: se control, market knowledge, stock selection ability and specific skill. It's 1early fou that najority of investors believe that they have complete knowledge of $\mathrm{m} / \mathrm{k}$ articularly ose investors who have many years of investment experience. They foun be confident of their specific skills that lead them to earn profits over their ir reswents.

When studied the level of optimism of optin ism among inves,ors in terms of their outlook of future of the stock market we found tha nvestors ary not much optimistic about the future of market.It's found that some investors to keep heir investment in the stock market only because the stock prices have declined an not want to sell their stock at a loss. Very few showed willingness of inci in investment in the stock market In next 12 months because they do not believe that st $\mathrm{kk}$ a ar. will not scale up immediately.

The dimension if investor invactor's in lvement is measured in terms of their trade activity and tendency to make alch honey. was fond that investors having short term profit seeking objectives are to to ave grea r level of involvement as compared to those with long term investment iech as mave greater tendency to make quick money in short time periods.

When measure ris reference of individual investors we found that investor' $S$ exhibit risk avers o havio they prefer investing in familiar companies with stable returns, but the are some in cors who showed a strong preference for taking risk. It's found that in stors th long lerm investment objectives and those with ages above 50 are more risk aven ien con ared to other.

ity on vest give the impression to have a preference to speculate with like nood $\mathrm{r}$ a gain malysis shows that individuals have inconsistent attitudes towards risk in rin decisions. They exhibit risk aversion have inconsistent attitudes toward in making investment decisions. They exhibit risk aversion in a profit making situation lo risk seeking behaviors. Is exhibited in a loss making situation that explains the phenomench of mental accounting .moreover the presence of disposition effect and representativeness are also confirmed by this study.

\section{CONCLUSION}

Participants of market have relied for a extended point in time on the conception of proficient market and rational investment behavior when making financial decisions 
However, the idea of fully rational investors constantly maximizing their utility and representing perfect self-control is not realistic and the market incompetence in the form of anomalies and absurd investors behavior have been pragmatic more often in the past decades. The consequences of greater extent study revealed that individual investors have high level of involvement and overconfidence while they are not much optimistic about the future outlook of market and moreover they have an aversion to risk.

\section{References}

[1] De Bondt F. M. W., Thaler H. R., The Journal of Finance XI(3) (1985)

[2] De Bondth Werner F. M., European Economic Review 42 (1991) 831

[3] De Bondth Werner F. M., Journal of Portfolio Mangement 18 (19' 4 84-

[4] Kahneman D (Ed.) (1982). Judgement under Uncertainty:

[5] Kenney, Derrick, (2003). Investor psychology plays ke Business Press. December, 5-11.

[6] Kent D., Hirshleifer D., Subrahmayam A., Journa of Fmance 56 91) 921-965

[7] Kent D., Hirshleifer D., Slew Hong Teoh, Jour al of Monetary Economics 49(1) (2001) 139-209.

[8] Larrick R., Boles T., Avoiding Regret ir Decision _ s 63 (1998) 87-97.

[9] Naughton Tony, Journal of Financial S vion racketing 7(2) (2002) 110-112.

[10]Peterson M. J., Journal of Finance 50 (19, 131-155

[11] Preacher R. J. R (1999). V ncons ous Hei 19 behavior as the psychological Basis of financial Market trends ma to syanchology and financial market.

[12]Ritter Jay, Finance ournal 11 903) 249-237.

[13] Shleifer A. (200, Ino, vient mar)ets.

[14] Siller R. J. (999). Human avior and the efficiency of the financial system. In Taylor

[15]J and Wor fford N Eds.). Handbook of Macroeconomics Amsterdam: Elsevier.

[16] Thaler R. ( . Ady hces in Behavioral Finance.

[17y hale .., Mark ng Science 4 (1985) 12-13.

[18] 4). The winner s Curse: Paradoxes and Anomalies of Economic Life.

[19] Tver, Kahneman D., Journal of Business 59 (1986) 251-294.

[20] Tverskya A.,Kahneman D., Journal of Science 185 (1976) 1124-1131.

[21] Yates J, (1990). Judgment and Decision Making Prentice Hall. P 118-127

[22]Belsky G., Gilovich T. (2000). Why smart people make Big Money Mistakes. 